\title{
The role of extracurricular religion in fostering the religious character of students
}

\author{
Wagiyo Wagiyo ${ }^{1}$, Nur Ahyani ${ }^{2}$, Destiniar Destiniar ${ }^{2}$ \\ ${ }^{1}$ Sekolah Menengah Pertama Negeri 8 Talang Ubi, Indonesia \\ ${ }^{2}$ Universitas PGRI Palembang, Indonesia
}

\begin{tabular}{|c|c|}
\hline Article Info & ABSTRACT \\
\hline Article history: & \multirow{8}{*}{$\begin{array}{l}\text { This research seeks to establish and explain the role of extracurricular religious } \\
\text { activities in promoting the religious character of students. This research, using } \\
\text { a descriptive approach, is a qualitative study. The study objective is to carry } \\
\text { out extracurricular religious activities in an attempt to instill the religious } \\
\text { beliefs of SMP Negeri } 8 \text { Talang Ubi students. The method of collecting data } \\
\text { from this analysis is through techniques of observation, interview and } \\
\text { recording. A technique that suits the data is used in analyzing this information, } \\
\text { namely descriptive data.It can be inferred from the results of the study that the } \\
\text { preparation of extracurricular religious activity activities, like majelis taklim, } \\
\text { reading and writing the Koran and praying in congregation, aims to build good } \\
\text { character in students and can instill a sense of faith and piety in students. }\end{array}$} \\
\hline Received Jul 9 $9^{\text {th }}, 2021$ & \\
\hline Revised Aug $12^{\text {th }}, 2021$ & \\
\hline Accepted Aug $30^{\text {th }}, 2021$ & \\
\hline Keyword: & \\
\hline Extracurricular & \\
\hline Religious & \\
\hline Character & \\
\hline
\end{tabular}

(C) 2021 The Authors. Published by IICET.

This is an open access article under the CC BY-NC-SA license

(https://creativecommons.org/licenses/by-nc-sa/4.0

\section{Corresponding Author:}

Wagiyo, W.,

Sekolah Menengah Pertama Negeri 8 Talang Ubi, Indonesia

Email: wagiyogiyo885@gmail.com

\section{Introduction}

The In reality, education that only gives preference to academic intelligence is not adequate as a provision of life. It is an imperative to provide a wide spectrum of intellectual intelligence, as intellectual intelligence is a means of meeting the demands of the times, especially in terms of developing human resources. However, intellectual knowledge alone is not enough. Since the noble values of the Indonesian country are not only to have great intellectual knowledge, but also to become a noble nation of noble character and culture.

As evidenced by the phenomena occurring among teenagers, particularly students who are the successors of the land, current phenomena make Indonesia insufficient to be called a nation of character. This pattern is such as loss of regard for teachers, parents, and those who should be respected, depriving others of their belongings, sacrificing courtesy, battling, cheating during tests, truancy, and free sexual behavior when learning. This is the degradation of the character of the homeland of Indonesia.

Education is one of the major breakthroughs in tackling the ongoing deterioration in character. Education is necessary not only in the field of science, but also in the field of religion. Intellectual and religious intelligence must be matched in order to deliver high-quality students in a balanced manner.

The required standard is consistent with the objectives of national education, namely to create the capacity of people who are committed to God the Almighty and who will always strengthen and nurture democratic 
attitudes, sustain good human-environmental ties, be physically healthy, and be able to establish esthetic power capable of building themselves and community.

In Indonesia, education must provide approaches or techniques that can be used to educate the student religious character of education. One of the strategies or tools used to instill religious character in students is by performing religious practices in schools, according to Setiyo[1], which can improve the confidence and obedience of students to the teachings of their faith.

These separate religious practices should be performed in schools and should be practiced by all pupils, so that the goals of character education and national education can be better accomplished. There are many ways in which religious character can be shaped, including through intra-curricular activities, namely the cultivation of integrated religious values in subjects of Islamic religious education, and through extra-curricular religious activities, namely through religious activities.

[2]Extracurricular activities are activities that are carried out to enrich and broaden the knowledge and expertise learned from various topics in the curriculum outside of face-to-face school hours. Extracurricular services in schools aim to supplement the learning process carried out in schools and are useful for applying the philosophy and experience learned as a practical consequence of the learning process, as well as extracurricular activities, in particular, religious extracurricular activities are supposed to increase the understanding of students, especially in the field of extracurricular activities.In addition, by integrating these religious extracurricular practices, the faith and piety of students to Allah SWT can also be reinforced by religious values.

Religious extracurricular practices carried out in schools are said to be successful if istiqomah is accomplished and the participation of students rises by participating in religious activities and competitions[3]. To this end, proper planning and preparing, as well as the preparation of program events for extracurricular religious experiences, are needed in order to accomplish the goal of fostering religious attitudes in schools.

SMP Negeri 8 in Penukal Abab Lematang Ilir Regency is an educational institution under the auspices of the KEMENDIKBUD Ministry of Culture and Education, which seeks to realize the values of the country, namely to educate students with a strong intellectual intelligence and religious character. Training in Islamic religious education only lasts 3 hours a week.

This has an influence on students in learning religious content. SMP 8 Talang Ubi, Penukal Abab Lematang Ilir Regency, then provides its students with a curriculum of activities in the form of extracurricular religious activities to support the religious needs of students. As recent extracurricular activities, such as those of the Taklim Board, have not so far been suitable for their implementation.

Since as many as 80 per cent of students at SMP Negeri 8 Talang Ubi had not yet been proficient in reading the Al-Quran after conducting interviews with teachers of Muslim Religion and Local Content Reading and Writing Al Quran, had not conducted five daily prayers at home, had not been able to practice purification correctly and had not recognized the value of practicing compulsory fasting at Holy Month of Ramadan.

The lack of participation of students in engaging in Iqra reciting activities arranged by mosques or village prayer rooms and the lack of parental roles to encourage their children to study religion. In addition, student behaviors are reflected in daily school life, including lack of ethics for students and appreciation for teachers.

Among other activities, the Taqlim Committee, the Dhuha prayer, the review of Iqro and the reading of Yasin's letters are part of religious extracurricular activities. It is also a means for students to better understand faith through these activities, in addition to increasing student abilities, which would later bring on a religious character through this comprehension. The researcher suggests, based on the context, the title of the report, "The Extracuricular Role of Religion in Growing Student Religious Characters".

\section{Method}

In this study, the researchers used a qualitative analysis approach. The researcher plays a very significant role in determining the final situation, so that the data rely most on the researcher. Researchers then used the observation approach at the time of data collection in the field. Participatory observation is a study characterized by social encounters that, according to Bogdan, take a long time between the researcher and the subject, cited by Lexy J. Moleong [3], and during that time is gathered by mudelatis and applied without interruption in the form of field notes. 
Social research uses a qualitative descriptive format that aims to identify, outline, classify, characterize, model, describe the various conditions, conditions, and different manifestations of social life that are the subject of research in society, and to try and bring reality to the surface. Or a description of certain circumstances, situations or phenomena. In research, the qualitative descriptive format is generally carried out in the form of case studies. This format does not have the features of water (spread to the surface) but relies on a single unit of various phenomena. This analysis may be more in-depth on the basis of those characteristics.

The aim of the study is to carry out extracurricular religious activities in an effort to instill the religious values of SMP Negeri 8 Talang Ubi students. The approach used to gather data from this study is through observation, interview and recording techniques. The data-adapting technique is used to evaluate this material, namely descriptive data.

\section{Results and Discussions}

From the results of the interviews, reports and documentation obtained at SMP Negeri 8 Talang Ubi, it can be seen that SMP Negeri 8 Talang Ubi continues to seek to increase the quality of education facilities in order to provide students with optimum learning outcomes. It can be seen in an effort to instill the religious values of students in administration, teaching and extracurricular activities, in particular in the conduct of religious extracurricular activities.

The school and, in particular, the supervisors of extracurricular religious activities also aim to maximize the ability of students to carry out religious extracurricular activities and also to ensure that the religious principles of students can be incorporated into students, so that they can operate seamlessly in the course of extracurricular religious activities, at school and, in particular, at school.

Character education is very critical in overcoming morality in Indonesia in the present sense [4], character education is a deliberate and planned attempt to internalize moral principles and morals in order to manifest them in the execution of positive attitudes and actions.Eighteen religious characters are involved in character education, integrity, tolerance, discipline, hard work, imagination, freedom, democracy, curiosity, national spirit, communication, peace-loving, reading, environmental care, social care, and transparency.

Character is one of the traits that can be trained for and lesson by a superior person and a person who can respond to technological innovations. The mental education of students is helped by this growth. They are applicants for the generation of a nation, who are added to have the spirit of a nation leader and to make a country with an adaptation, a character capitalization carried out by a generation of a nation with character. To uphold the noble values of the country with sound morality and principles, and to be a deeply knowledgeable generation adorned with faith and godliness[5].Character is often associated with personal behavior, ethics, morals, or personality [6].

\section{Planning for extracurricular worship events at SMP Negeri 8 Talang Ubi}

Preparation for the SMP Negeri 8 Talang Ubi extracurricular religious activity program is that this program takes place after the hours of the religious lessons, with a schedule of once a week. The Taklim Council, the Reading and Writing of the Koran and the Prayers in the Congregation are the aims of this activity, each of which is attended by a religious field teacher with the intention of influencing the ideals of religious or Islamic character in students.

With a range of programs established, SMP Negeri 8 Talang Ubi is planning extracurricular religious activities. Iqro reading, congregational prayer and the taklim council are the program of extracurricular worship events carried out in an effort to instill the religious values of students. It will be carried out on Saturday under the planned extracurricular schedule for the introduction of Iqro Reading. The Taklim Council takes place every Friday and the Dzuhur Congregational Prayer takes place every day.

\section{Implementation of extracurricular religious events in an attempt to instill religious values for students at SMP Negeri 8 Talang}

It can be concluded from the supervisor's explanation that the SMP Negeri 8 Talang Ubi religious extracurricular activity program is well underway. This procedure is very respectful of the theory. When arranged according to a set timetable, this practice is also carried out without interrupting intra-curricular activities. By habituation as a method of application in everyday life, the contributions made in this task will remain in the hearts of students and will do so regularly and without intimidation. 
Broadly speaking, it can be concluded from the above two statements that some reasons that encourage the initiation of extracurricular religious activities at SMP Negeri 8 Talang Ubi are as follows: (a) student motivation; (b) student enthusiasm; and (c) parental support.

\section{Evaluation of the introduction of extracurricular religious practices in the attempt to infuse the religious beliefs of students}

Activities must have the purpose that is important to encourage students to carry out predetermined competencies by activities such as the conduct of extracurricular religious activities in an effort to instill the religious beliefs of these students. In order to accomplish the desired goals, this activity must also have competencies and must be met by students.

The goal of carrying out this extracurricular religious activity is none other than to encourage students to further improve their even better attitudes, behaviors and customs, especially those that are Islamic, given that the current situation is very worrying, particularly in terms of the habits of young people. Those who are more inclined to worldly things, such as congregational worship, seldom have to do so at home. It would be difficult to control their bad habits, particularly those who are Islamic in nature, unless they are nurtured from an early age.

The evaluation carried out at SMP Negeri 8 Talang Ubi on the application of the Extracurricular Religion Curriculum was to determine the conduct of religious practices using observation and supervision techniques. Techniques of observation of acts that take place in the daily lives of school children, as well as the records of activities committed at home. The appraisal is carried out once a month in collaboration with teachers and home-room teachers and with the participation of parents at home.

Students gain useful insight through this program in religious extracurricular practices, such as being able to read Al-Qur'an, understand how to live and learn how to pray.

The religious morality or identity of the students of SMP Negeri 8 Talang Ubi can eventually be changed after evaluating the schedule of religious extracurricular activities that are regularly carried out every month. From the findings of the observations, it can be seen that the behavior of more respectful students in classes, ways of speaking and enthusiastic participants in religious activities is also increasing. Students who can read the iqro can begin to read the Koran gradually and learn the contents of the verses of the Al-Qur'an. Students have good habits, particularly in carrying out the task of carrying out orders of prayer.

\section{Conclusions}

After the author describes the introduction of extracurricular religious activities in an effort to instill the religious values of students at SMP Negeri 8 Talang Ubi, it can be inferred that the purpose of the planning of programs for extracurricular religious activities is to develop a strong character in students and to encourage a sense of faith and piety in students. The Taklim Council, Read and Write the Al-Qur'an and Pray in the Congregation are services of religious activity.The implementation of extracurricular worship events is carried out on a regular basis by schedule. Every Friday, Majelis Taklim, Read and Write Iqro every Saturday, and Congregational prayers include Dhuha morning prayers, Dzuhur daily prayers, and Friday prayers. Attempts are made, by normal procedures, to instill religious beliefs in students. Evaluation of religious extracurricular behaviors is carried out on a weekly basis by daily reviews of extracurricular observation strategies instructors, practical activity success methods and portfolio techniques by student behaviour studies.

\section{References}

Susetyo, A. I. (2018). Implementasi Ekstrakurikuler Berbasis Agama Islam di MTs. Darul Hasanah Genuk Semarang. Semarang: Fakultas Ilmu Tarbiyah dan Keguruan Universitas Islam Negeri Walisongo Semarang.

Suryasubroto. (2002). Proses Belajar Mengajar di Sekolah. Jakarta: PT Rineka Cipta.

Avisina, S. R. (2016). Pelaksanaan Kegiatan Esktrakulikuler Keagamaan dalam upaya menanamkan nilai religius islam di MTs Jambewangi Selaputra Blitar. Malang : Universitas Islam Negeri Maulana Malik Ibrahim.

Hambali, M. \&Yulianti, E. (2018). Ekstrakurikuler Keagamaan Terhadap Pembentukan Karakter Religius Peserta Didik di Kota Majapahit. Jurnal Pedagogik. 05 (2). Diunduh melalui https://ejournal.unuja.ac.id diakses tanggal 28 November 2020. 
Ainiyah, N. (2013). Pembentukan Karakter Melalui Pendidikan Agama Islam. Jurnal Al-Ulum (Jurnal StudiStudi Islam) IAIN Gorontali, 13 (1).

Lian, B., Kristiawan, M., Primasari, D. A. G., \& Prasetyo, M. A. M. (2020). Teachers' Model In Building Students' Character. Journal of Critical Reviews, 7(14), 927-932. 